\title{
THE TRIASSIC TAPHOFLORA FROM PARANA BASIN, SOUTHERN BRAZIL: AN OVERVIEW
}

\section{MARGOT GUERRA-SOMMER AND MIRIAM CAZZULO KLEPZIG}

\begin{abstract}
A Triassic Dicroidium Flora identified in the central region of the State of Rio Grande do Sul, Southern Brazil, represents an important biostratigraphic stage in the palaeofloristic succession of Parana basin.

The megafloristic association composed of compressed leaves, fronds and seeds shows a predominance of the genus Dicroidium, with several species, and other important taxa like Neocalamites sp, Cladophlebis sp., Tetraptilon aff. heteromerum, Ginkgoites antarctica, Sphenobaiera $\mathrm{sp}$, Podozamites sp, Nilssonia sp, Pteruchus sp and Carpolithus sp. Taking into account the stratigraphic distribution of different species of the genus Dicroidium, a biostratigraphic framework was previously established and an informal floristic interval, named "Dicroidium odontopteroides Flora" was proposed (Late Anisian to Late Ladinian, Middle Triassic). The general composition of the Dicroidium Flora in Rio Grande do Sul is similar to the "Dicroidietum odontopteroidium" characterized for Australasia corresponding to a forest association composed by trees, woody shrubs, ground cover and swamps growths. The presence of xilopteroid leaves indicates levels of water stressed substrate. The homogeneous composition of the assemblage, and the small size of leaves of the whole association in relation to the Dicroidium Flora of other Gondwana regions (e. g. Molteno Formation) seems to indicate particular drainage patterns prevailing during deposition of Santa Maria Formation.
\end{abstract}

Keywords'. Dicroidium Flora, South Brazilian Gondwana, Anisian, Ladinian.

\section{INTRODUCTION}

The present study aims to update biostratigraphic and palaeoecological information about plant fossils present in the Triassic sequences of Parana basin in Rio Grande do Sul state, Southern Brazil; results obtained gave an overall picture of the knowledge of the Dicroidium Flora, that represents an important stage in the palaeofloristic succession of Parana basin.

Naturalists made the first references to Mesozoic plant fossils in the state of Rio Grande do Sul at the end of the last century (AveLallemant 1880, Isabelle 1883). Until the fifties these fossil plants were just mentioned, together with reptiles, as biostratigraphic markers in studies that tried to establish the stratigraphy of the gondwanic series in Southern Brazil (White 1908, Moraes Rego 1930, Huene \& Stahlecker 1931, Fiuza da Rocha \& Scorza 1940, Gordon Jr. 1947, Beurlen et al. 1955, Rau 1933, Gordon Jr. \& Brown 1952, Pinto 1956). From 1965 on, studies on frequency, location of stratigraphic horizons were developed (Beltrao 1965, Bortoluzzi \& Barberena 1967, Bortoluzzi 1975). Bortoluzzi \& Barberena (1967), for the first time, interpreted megaplant association as representatives of the so-called "Thinnfeldia-Dicroidium Flora", nowadays named "Dicroidium Flora".

After 1980 important contributions concerning Dicroidium Flora of Rio Grande do Sul were carried out (Bortoluzzi et al. 1983, 1984 and 1985, Guerra-Sommer et al. 1985, Mastroberti 1997, lannuzzi \& Schultz 1997, Guerra-Sommer et al. 1998, Guerra-Sommer et al. 1999). These studies have resulted in a substantial increase in the knowledge of the flora. Sequences containing Dicroidium flora were dated as Triassic, according to the criteria of Gamermann (1973), Bortoluzzi (1973), Andrei (1980) and Faccini (1989).

Using sequence stratigraphy, Milani et al. (1997) characterize six megasequences for the Paleozoic and Mesozoic intervals of the Parana basin. According Milani et al. (1997) the depositional history of Parana basin produced continental sequences controlled by tectonism and climatic changes. The late Triassic Megasequence (ITr) is represented, in the southern part of the basin, by the Santa Maria Formation (Fig 1). According to these authors, the sediments of this unit were formed in a fluvial/lacustrine environment.

Sedimentary sequences containing the best deposits of leaf impressions are located close to the city of Santa Maria mainly in outcrops named by Bortoluzzi (1974) as Passo das Tropas and Dom Antonio Reis, both linked to the same stratigraphic level, which corresponds to a conglomerate with interbedded mudstone levels Fragmentary plant collections were registered in siltstones and mudstones from Hospital and Olaria outcrops, which correspond to the basal part of the sequence outcropping at Passo das Tropas locality.

THE SOUTHERN BRAZILIAN "DICROIDIUM FLORA" Based on the above mentioned studies, the Dicroidium Flora in Rio Grande do Sul State is composed of following elements, according to taxonomic studies of Bortoluzzi et al. $(1983,1984,1985)$ and GuerraSommer et al. $(1985,1999)$ :

SPHENOPHYTA - Neocalamites sp.

PTERIDOPHYLLA - Cladophlebis sp.

Tetraptilon aff. T. heteromerum Frenguelli 1950
Dicroidium lancifolium (Morris) Gothan 1912

Dicroidium (Johnstonia) stelzneriana (Gein.) Frenguelli 1941

Dicroidium (Xylopteris) argentinum (Kurtz) Arrondo 1972

Dicroidium lancifolium Petriella 1978

Dicroidium (Xylopteris) elongatum (Carruthers) Archangelsky 1968

Dicroidium odontopteroides (Morris) Gothan 1912

Dicroidium odontopteroides var. odontopteroides (Morris) Gothan 1912

Dicroidium odontopteroides var. remotum (Szajnocha) Retallack 1977

Dicroidium odontopteroides var. moltenense Retallack 1977

Dicroidium zuberi var. zuberi (Szajnocha) Archangelsky 1968

Dicroidium zuberi var. papillatum (Townrow) Retallack 1977

Dicroidium zuberi var. brasiliensis Petriella 1978

Dicroidium zuberi var.feistmantelii (Johnston) Retallack 1977

Dicroidium dubium Jacob \& Jacob 1950

Dicroidium aff. narrabeenense (Dun in Walkom) Jacob \& Jacob 1950

Pteruchus sp.

GINKGOPHYTA - Ginkgoites antartica (Saporta) Shirley 1898

Sphenobaiera sp.

CYCADOPHYTA - Williamsonia sp.

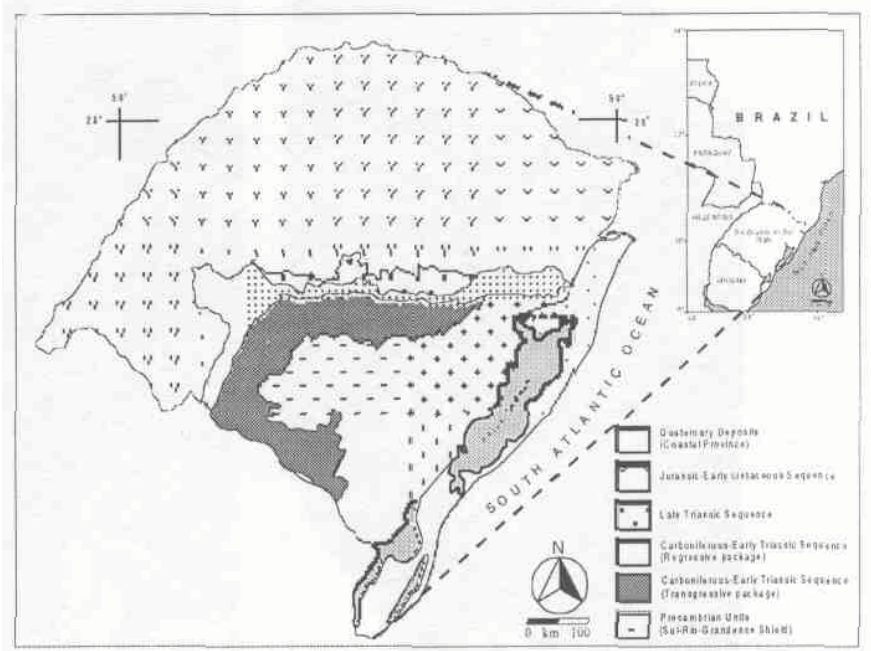

Figure 1 - Location of the Gondwana Sequence in Rio Grande do Sul, southern Brazil (modified after Scherer et al. 1999) 
CONIFEROPHYTA - Podozomites sp.

INCERTAE SEDIS - Taeniopteris sp.

Sewardia sp.

Nilssonia sp.

Carpolithus sp.
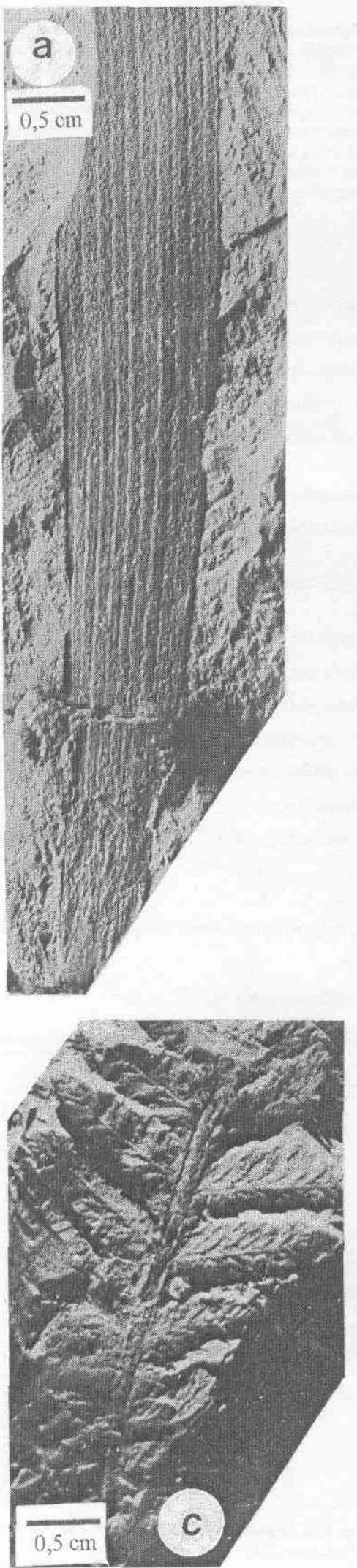

The most important taxa collected from Passo das Tropas outcrop are illustrated in figs. 2, 3 and 4, al material mentioned in this paper is kept at the Palaeobotany section, Institute of Geosciences, UFRGS.

Barberena \& Bortoluzzi (1977) suggested a preliminary biostratigraphic zoning for Santa Maria Formation with two tetrapod biozones: Therapsida Cenozone and Rhyncocephalia Cenozone, with an "intermediate biozone" of Dicroidium. Guerra-Sommer et al.
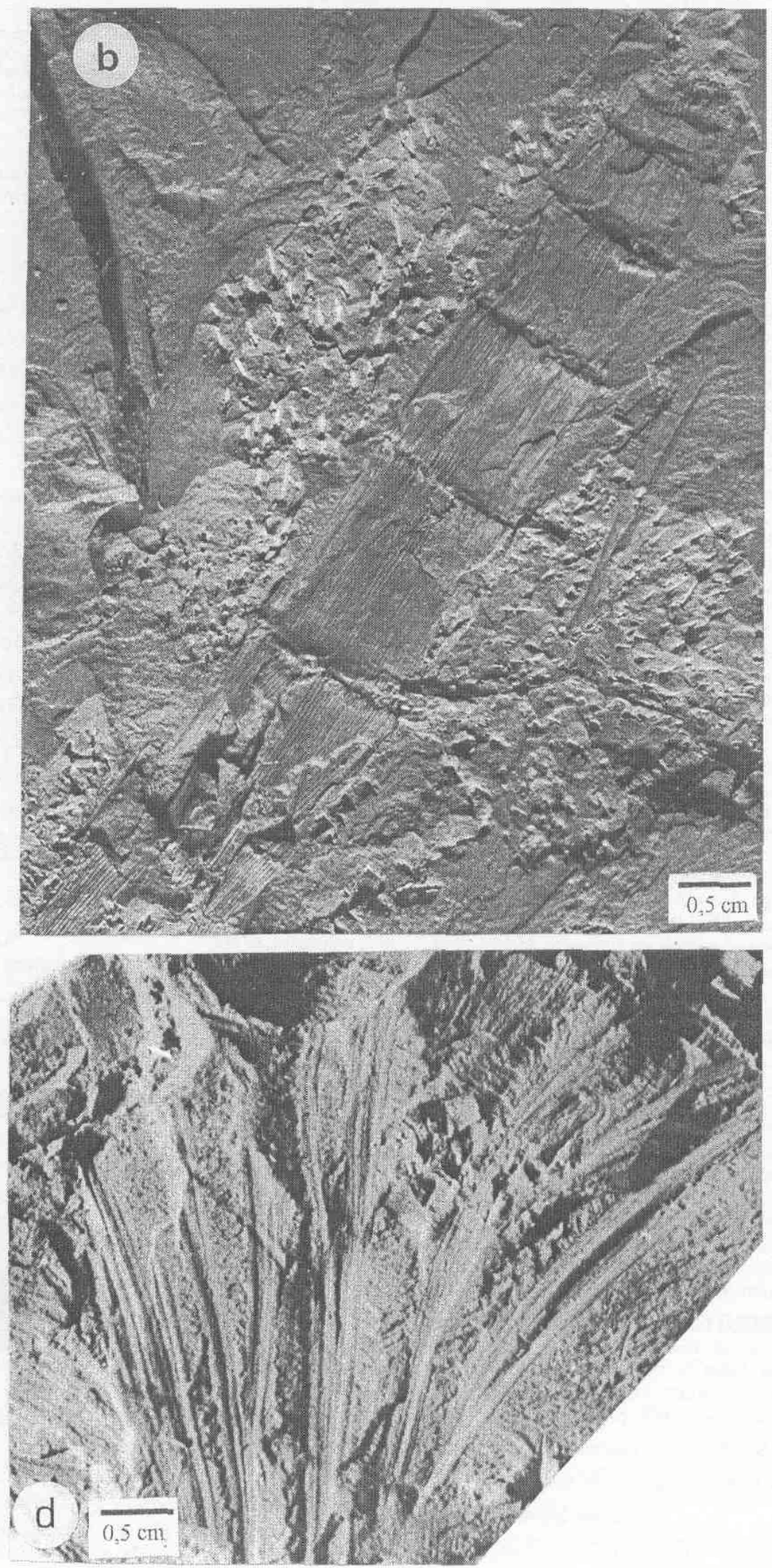

Figure 2 - $a$ - Podozamites sp.; $b$-Neocalamites sp.; c - Chladophlebis sp.; $d$ - Sphenobaiera sp. 
(1985) include the Dicroidiwn Flora of Rio Grande do Sul in the Dicroidium odontopteroides "oppel-zone" of Retallack 1977. Barberena et al (1993) kept the Therapsida and Rhyncocephalia Cenozones, but suggest abandoning the Dicroidium Cenozone proposed by Barberena \& Bortoluzzi (1977).

Aiming the fitostratigraphic refinement of Triassic sequence in
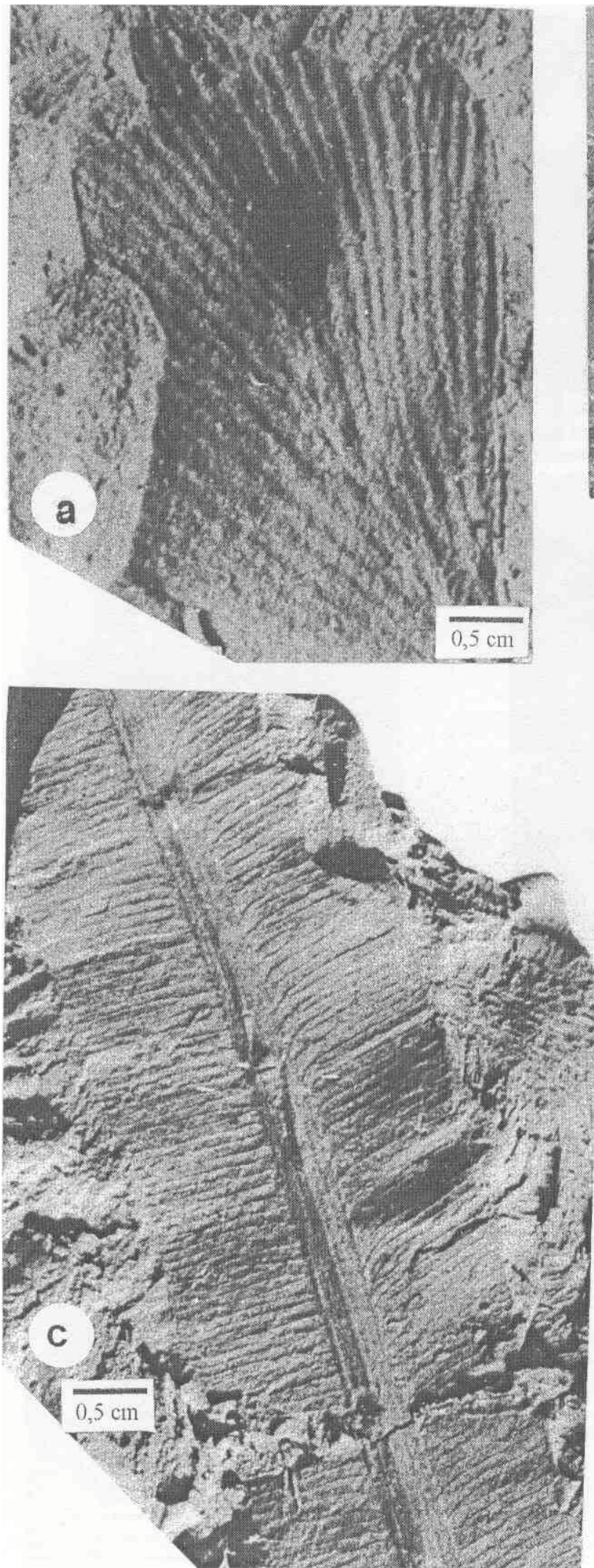

southern Brazil, the stratigraphic distribution of different species of the genus Dicroidium has been taken as the main reference for the study of Guerra-Sommer et al. (1999). A chart was built based on the maximum stratigraphic range presented by Retallack (1977) and Petriella (1983) for species of Dicroidium in Australasia and Argentina, respectively. The species of Dicroidium occurring in southern
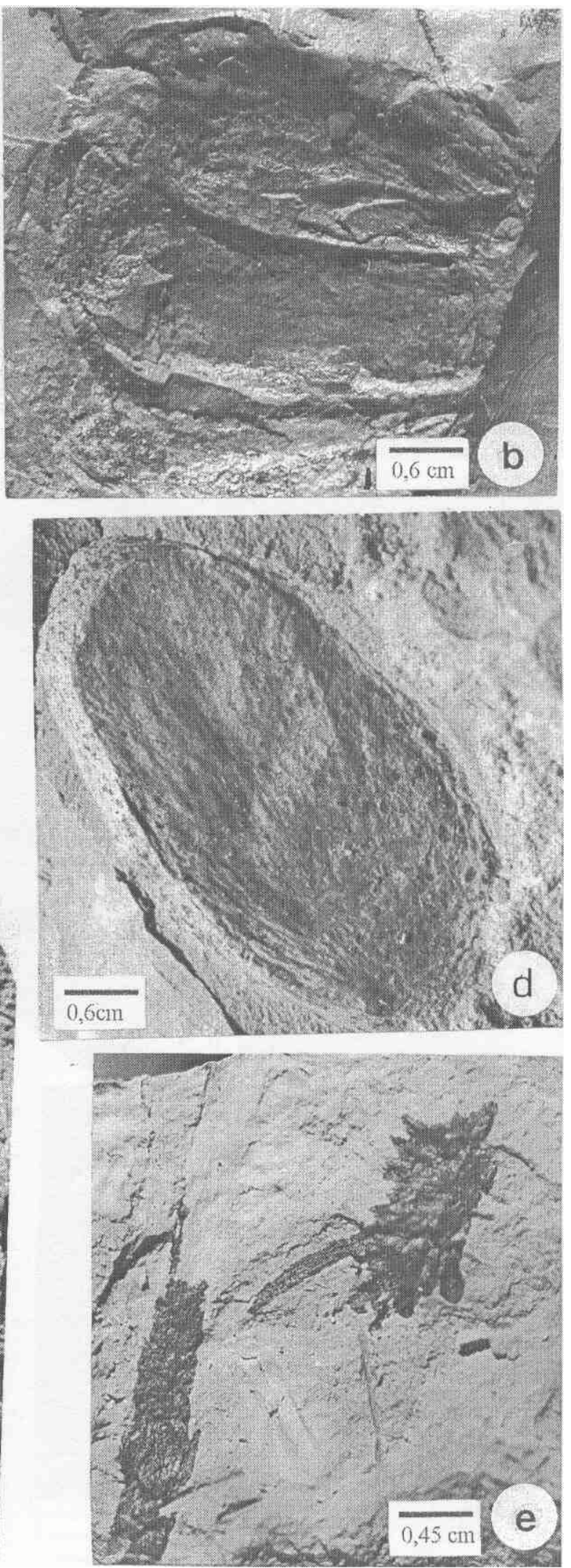

Figure 3 - a - Ginkgoites antactica; $b$ - Williamsonia sp.; c - Taeniopteris sp.; $d$-Carpolithus sp.; e - Pteruchus sp. 
Brazil indicated a time interval corresponding to Neo-Anisian/NeoLadinian (Middle Triassic). Dicroidium odontopteroides var. remotum represents the taxon of greatest biostratigraphic value in the association (Fig. 2).

Guerra-Sommer et al. (1999) concluded that the characteristics presented by the studied associations, such as diversity of species and abundance of specimens associated with the limited geographic and stratigraphic occurrence, were insufficient for the establishment of a formal zoning. An informal palaeofloristic interval named "Dicroidium odontopteroides Flora" was therefore suggested.

The general composition of Dicroidium Flora in Rio Grande do Sul state is similar to the "Dicroidietum odontopteroidium" Floral
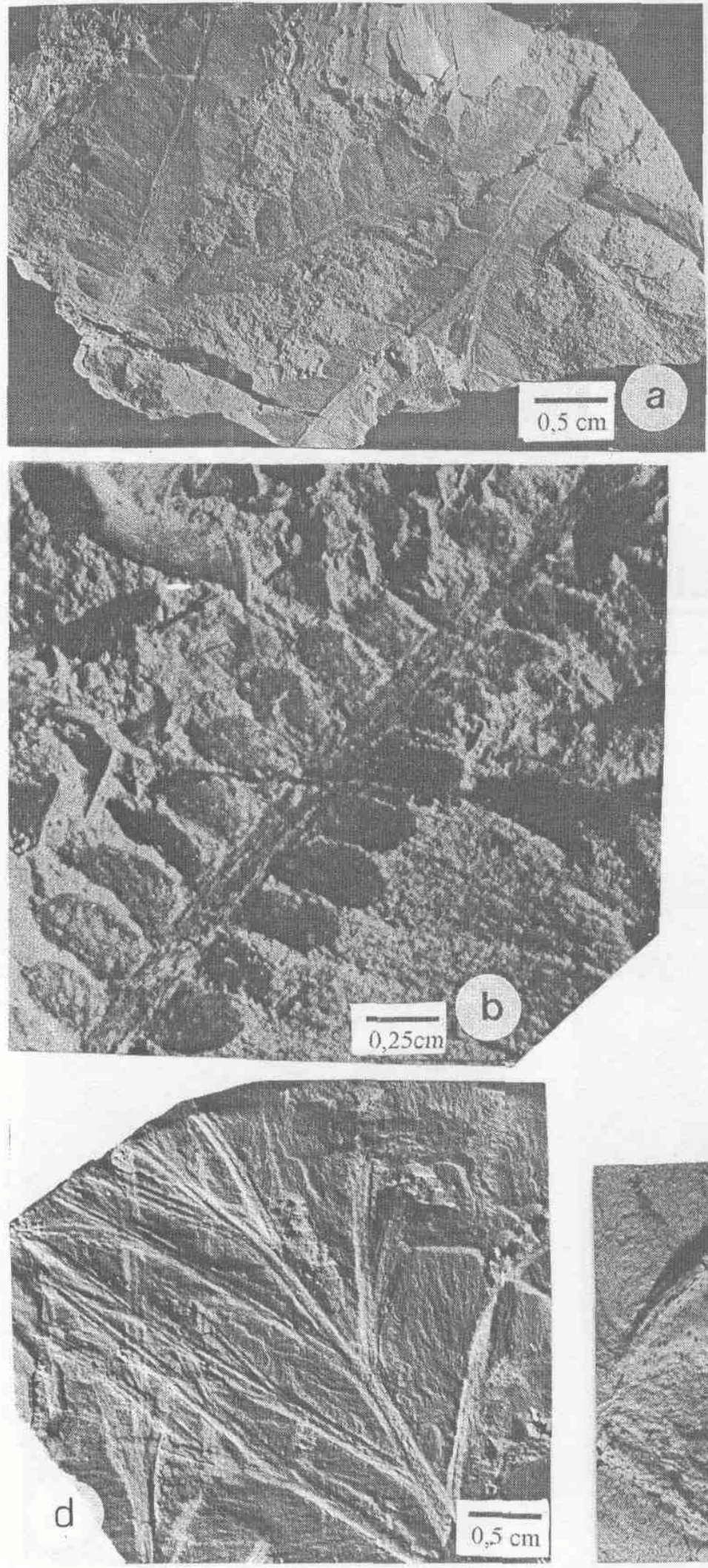
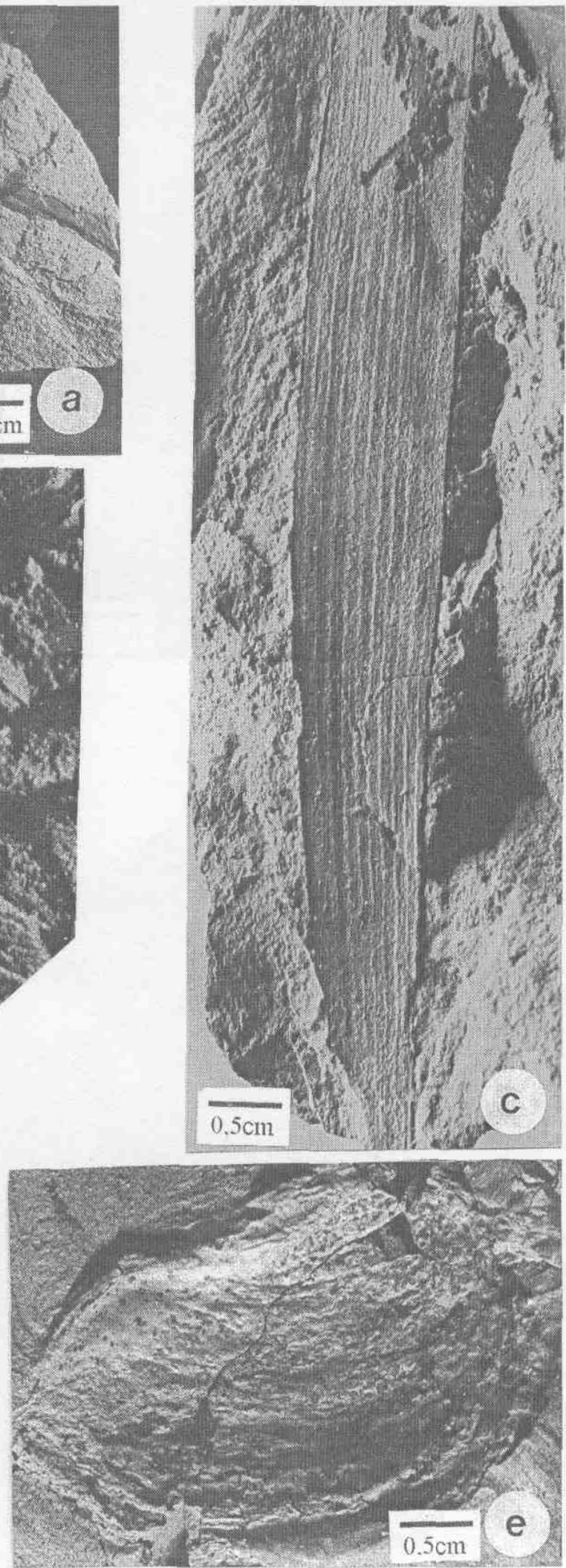

Figure 4 - a - Dicroidium odontopteroides; $b$ - Tetraptilon aff. heteromemm; c- Podozamites sp.; d-Dicroidium (Xylopteris) elongatus; e-Carpolithus sp. 
association, characterized by Retallack (1977) for Australasia. This phytoassociation was probably composed of a variety of structural elements, including trees (conifers, ginkgophytes and pteridosperms), woody shrubs (Nilssonio), ground cover (ferns) and swamps growths (sfenophytes). The paleoflora was developed both in meandering and braided channel deposits in fluvial and lacustrine systems.

The most diversified and abundantly preserved plant group was related to Dicroidium, represented by forms with an expanded leaf area, as $D$. odontopteroides for instance.

A drier paleoenvironment suggested by the presence of Dicroidium (Xylopteris) elongatum and Dicroidium (Xylopteris) argentinum forms with reduced leaf area and also supported by other associated narrowlived species of Sphenobaiera, are indicatives of xerophillous paleoenviroment. These forms can be related to Retallack's "Dicroidietum odontopteroidium xilopterosum" phytoassociation, developed in a low fertility, water stressed substrate, in the flood plain.

In general, the pattern of vegetation throughout the plain was probably fairly uniform. Local variation certainly occurred in different specialized habitats, as it seems to be demonstrated by the Olaria outcrop plant assemblage (Bortoluzzi 1974), where Podozamites occur almost as an exclusive form.

The paleofloristic data are in agreement with the idea of Faccini (1989) and Scherer (1994) using facies analysis which indicate a strong climate control over sedimentation in the Santa Maria Formation.
It is important to point out that the whole association of "Dicroidium Flora," belonging to the South Brazilian sequence is homogeneous when compared with the exuberance of the Trjassic Molteno assemblage, South Africa (Anderson 1974), The leaves are, on the other hand, only a half or a third the size of those of South African assemblage, This change of leaf size in leaves of the same species in correlated stratigraphic horizons could be related to water deficit or dryness of climate. Thus, the trend toward enrichment in species and the appearance of new types, and the expanded leaf size, could be related to the paleogeographic position of South Brazilian an South African Gondwana during the Triassic global greenhouse stage.

Considering the similar latitudes (near $60 \mathrm{~S}$ ) between Parana and Karro Basins at the Ladinian-Anisian interval (Smith et al 1994) distinct drainage patterns could be responsible for the different characteristics of the paleofloras.

According Ryan 1967 (in Anderson 1974) the physiographic conditions that prevailed during Molteno times indicates that the Molteno Plain was a depressed region, surrounded by highland areas, with a poor drainage exit. Consequently, swamp conditions were established, originating a rich Dicraidium Flora, with large size leaves. In Parana basin, on the other hand, at this time better drainage patterns allow drier conditions and the development of a floral association adapted to seasonal paleoenvironment.

Acknowledgements To two referees of RBG for the critical review of the manuscript.

\section{References}

Anderson H. M. 1974. A brief review of the Flora of the Molteno Formation (Triassic), South Africa. Paleontologia Africana, 17:111-129

Andreis R.R., Bossi G.E., Montardo D. K. 1980. O Grupo Rosario do Sul (Triassico) no Rio Grande do Sul, Brasil. Anais, $31^{\circ}$ Congresso Brasileiro de Geologia, Camboriú 2, 659-673.

Ave-Lallemant R. 1980. Viagem pela provincia do Rio Grande do Sul (1858). ItatiaiaEDUSP, Sao Paulo, $417 \mathrm{p}$.

Barberena M. C., Bortoluzzi C.A. 1977. Bioestratigrafia preliminar da Formafao Santa Maria. Pesquisas, 7:111 -129.

Barberena M. C, Faccini U. F., Scherer C. M. S. 1993. Situação Atual e Perspectivas da Bioestratigrafia da Formacao Santa Maria. Resumos, Simpósio sohre Bioestratigrafia da Formacao Santa Maria. Resumos,
Cronoestratigrafta da Bacia do Parana Rio Claro, 1,100-103.

Beltrao R. 1965, Paleontologia de Santa Maria e Sao Pedro do Sul, Rio Grande do Sul, Brasil. Boletim Jo Institutode Ciencias Naturals da Universidade Federal de Santa Maria, 2, 3-114

Beurlen K., Senna Sobrinho M., Martins E. 1955. Formações Gondwânicas do Rio Grande do Sul. Boletim do Museu National, 22:1-55

Bortoluzzi C. A. 1974. Contribui9ao a Geologia da Região de Santa Maria, Rio Grande do Sul, Brasil. Pesquisas, 4:7-86.

Bortoluzzi C. A. 1975. Etude de quelques empreintes de la flore gondwanienne du Brésil Actes du 95 ieme Congres National des Societes Savantes, Sciences, Reims, France (1970), till, 171-187.

Bortoluzzi C. A. \& Barberena M. 1967. The Santa Maria Beds in Rio Grande do Sul (Brazil). In: Problems in Gondwana Geology, (edited by Bigarella J. J., Becker R. D., Pinto I. D.), pp. 169-196. Universidade Federal do Paraná, Curitiba, 344p.

Bortoluzzi C. A., Guerra-Sommer M., Cazzulo-Klepzig M, 1983. Tafoflora Triássica da Formação Santa Maria, RS, Brasil. 1. Equisetales, Ginkgoales, Coniferales e Pteridophylla. Anais, $8^{\circ}$ Congresso Brasileiro de Paleontologia, Rio de Janeiro, 2:539-549.

Bortoluzzi C. A., Guerra-Sommer M-, Cazzulo-Klepzig M. 1984. Tafoflora Triássica da Formação Santa Maria, RS, Brasil. II- Representantes de Pteridospermopsida e Pteridophylla. IV Reuniao de Paleobotanicos e Palinologos, USP, Sao Paulo. Boletim $I G ., 15: 105-115$

Bortoluzzi C. A., Guerra-Sommer M., Cazzulo-Klepzig M. 1985. A Tafoflora Triássica da Formação Santa Maria, RS, Brasil: III Dicroidium odontopteroides, Dicroidium zuberie variações relacionadas a estas espécies. Pesquisas, 17:215-232.

Fapcini U.F. 1989, O Permo-Triássico do Rio Grande do Sul. Brasil. M. Sc. Dissertation (unpubl.), Universidade Federal do Rio Grande do Sul, Curso de P6s-Graduação em Geociencias, Porto Alegre, $121 \mathrm{p}$.

Fiuza da Rocha J. \& Scorza E. P. 1940. Estratigrafia do Carvão em Santa Catarina. Boletim da Divisao de Geologia e Mineralogia, 104, 1-162.

Gamermann, N. 1973. Formação Rosário do Sul, Pesquisas, 2:5-35.

Gordon Jr. M. 1947. Classification of the Gondwanic Rocks of Parana, Santa Catarina, and Rio Grande do Sul. Notas Preliminares e Estudox, Divisao de Geologia e Mineralogia, \&l, 1-19.

Gordon Jr. M. \& Brown R. 1952. Plantas Triássicas do Rio Grande do Sul. Notas Preliminares e Estudos, Divisão de Geologia e Mineralogia, 54, 1 -7.

Guerra-Sornmer M., Cazzulo-Klepzig M., Bortoluzzi C. A. 1985. A Tafoflora Triássica da Formação Santa Maria, Bacia do Parana, Brasil e sua Irnportância Bioestratigrafica. Memoria, $3^{\circ}$ Congreso Latinoamericano de Paleontologia y Simpósio sabre Floras del Triássico Tardio, Su Fitogeografta y Paleoecologia, Mexico, 33-41.
Guerra-Sommer M., Cazzulo-Klepzig M., lannuzzi R. Alves L. S. R. 1998. A Flora Dicroidium no Rio Grande do Sul: implicações bioestratigraficas. Pesquisas, 26s39

Gueira-Sornmer M., Cazzulo-Klepzig M., lannuzzi R. 1999. The Triassic taphoflora af the Parana basin, southern Brazil: a biostratigraphical approach. Journal of African Earth Sciences, 29:243-255.

Huene F, V. \& Stahlecker R. 1931. Observacões geológicas no Rio Grande do Sul, Baletim da Instituto de Ciências Naturais da Universidade de Santa Maria, 3:3-99.

lannuzzi R. \& Schultz C. L. 1997. Primeiro registro de megaf6sseis vegetais no Membra Alemoa da Formação Santa Maria, RS (Trifosico M\&Jio a Superior), Boletim de Resumos, $15^{\circ}$ Congresso Brasileiro de Paleontologia, Aguas de São Pedro, 35.

Isabelle A. 1983. Viagem ao Rio Grande da Sul, 1833-1834, Martins Uvreiro, Porto Alegre, $2^{\mathrm{a}}$ ed., $165 \mathrm{p}$

Mastroberti A. A. 1997, Contribuição ao Estudo do Genero Dicmidium (Gothan, 1912) Townrow 1957, na Formação Santa Maria (Brasil, Rio Grande do Sul), Bacia do Paraná Acta Geologica Leppoldensia, 44(20):83-86.

Milani E.J., Faccini U, F, Scherer C. M., Araujo L. M., Cupertino J. A, 1997, Sequences and stratigraphic hierarchy of the Parani basin (Ordovjcian to Cretaceous), Southern Brazil. In: Sedimentary Basins of South America, A- J. Amos (ed.), in press.

Moraes Rego L. F. J 930, Geologia do Petróleo no Estado de São Paulo, Boletim do Servico Geologico e Mineraldgico, 46,1 -105,

Petriella B. 1983, Sinopsjs de las Corystospermaceae (Corystosperpales, Pteridospermophyta) de la Argentina. Ill Troncos y Cronoestrqtigrafia. Ameghiniana, 20:41-46.

Pinto I. D. 1956. Artrópodos da Formafão Santa Maria (Triássico Superior) do Rio Grande do Sul, com notícias sobre alguns restos vegetais. Boletim da Sociedade Brusileira de Geologia, 5:75-87.

Rau W. 1933. Cedroxylon canoasense, una madera fosil nueva del Rio Grande del Sur. Revista Sudamericana de Botanica, 1:169-172.

Retallack G. 1977. Reconstructing Triassic vegetation of Eastern Australasia: a new approach for the Biostratigraphy of Gondwanaland. Alcheringa, 1:247-77.

Scherer C. M. 1994. Andlisefaciologica e bioestratigrdfica do Triássico Superior (topo da Formação Santa Maria) na regiao de Candeldria - RS. Universidade Federal do Rio Grande do Sul, Curso de Pós-Graduação em Geociências, Porto Alegre, M. Sc Dissertation, $101 \mathrm{p}$

Scherer C. M., Faccini U.P., Lavina L. E. 1999, Bacia do Parana - a sucessão mesozóica. Editora da Universidade, UFRGS, Porto Alegre, (no prelo).

Smith A. G. \& Funnell B. M. 1994. Atlas of Mesozoic and Cenozojc Coastlines. Cambridge University Press, Cambridge. 99p

White D. 1908. Flora fossil das Coal Measures do Brasil. In: Relatorio Final, Comissão de Estudos das Minas de Carvão de Pedra do Brazil, (edited by White, I. C.), pp. 337 617, Imprensa Nacional, Rio de Janeiro, v. 3,280p. 